\title{
CONTENTS.
}

\author{
Vor. XI, No. 3.
}

PAGE

1. OldHast, J. N. On Howardula phyllotretae n. sp, a Nematode Parasite of Flea Beetles (Chrysomelidae; Coleoptera), with Some Observations on its Incidence $\quad \ldots . \quad \ldots$

2. Carroll, J. A Study of the Potato Eelworm (Heterodera schachtii) in the Irish Free State ... ... ... ...

3. Soromon, S. G. The Helminth Parasites of Dogs in $\begin{array}{llllllll}\text { Marseilles } & \ldots & \ldots & \ldots & \ldots & \ldots & \ldots & \ldots\end{array}$

4. Thapar, G. S. A New Blood Fluke from an Indian Tortoise, Trionyx gangeticus $\quad \ldots \quad$... $\quad \ldots . \quad \ldots$

5. Morgan, D. O. The Effect of Heavy Stocking on the Worm Burden under a System of Rotational Grazing

\section{Publications of the}

\section{Institute of Agricultural Parasitology}

(LONDON SCHOOL OF HYGIENE AND TROPICAL MEDICINE)

JOURNAL OF HELMINTHOLOGY. Edited by R. T. LEIPER, M.D., D.Sc., F.R.S.

Issued quarterly, or more frequently as occasion demands, for the publication of original communications by the Staff and Associated Workers of the Institute.

Subscription Price 25/-net a volume, post free. Volumes $I$ to $X$ bound in cloth, price $30 /-$ net each, post free.

HELMINTHOLOGICAL ABSTRACTS. Edited by R. T. LEIPER, M.D., D.Sc, F.R.S. With the co-operation of B. G. PETERS, Ph.D., M. J. TRIFFITT, D.SC.; and T. W. M. CAMERON, D.S., M R.C.V.S.

Issued in five parts annually (by arrangement with the Imperial Bureau of Agricultural Parasitology) for the publication of abstracts of original papers on applied helminthology which appeat in current periodicals.

Subscription Price $16 / 6$ net a volume, post free.

Separate parls, price $4 /-$ each, posi free.

Both publications are obtainable through any bookseller, or direct from the Institute of Agricultural Parasitology, Winches Farm Drive, Hatfield Road, St. Albans, Herts., England. 